Cooper, A. K., P. J. Barrett, H. Stagg, B. Storey, E. Stump, W. Wise, and the 10th ISAES editorial team, eds. (2008). Antarctica: A Keystone in a Changing World. Proceedings of the 10th International Symposium on Antarctic Earth Sciences. Washington, DC: The National Academies Press. doi:10.3133/of2007-1047.kp01

\title{
Summary and Highlights of the 10th International Symposium on Antarctic Earth Sciences
}

\author{
T. J. Wilson, ${ }^{1}$ R. E. Bell, ${ }^{2}$ P. Fitzgerald,${ }^{3}$ S. B. Mukasa,${ }^{4}$ R. D. Powell,${ }^{5}$ C. Finn ${ }^{6}$
}

\section{INTRODUCTION}

The 10th International Symposium on Antarctic Earth Sciences (10th ISAES) was convened at the University of California, Santa Barbara, in August 2007. At the symposium about 350 researchers presented talks and posters with new results on major topics, including climate change, biotic evolution, magmatic processes, surface processes, tectonics, geodynamics, and the cryosphere. The symposium resulted in 335 papers and extended abstracts (Cooper et al., 2007, and this volume). Many science discoveries were presented spanning the last 2 billion years, from times when Antarctica was part of former supercontinents Rodinia and Gondwana to the present when Antarctica is an isolated, ice-covered land mass surrounded by seafloor spreading centers. In this summary we highlight some of the new results presented at the symposium.

\section{TECTONICS IN THE SOUTH: A VIEW FROM THE SOLID EARTH}

Antarctica occupies a key position for a greater understanding of the evolution of the supercontinents Rodinia and

${ }^{1}$ School of Earth Sciences, Ohio State University, Columbus, OH 432101522, USA.

${ }^{2}$ Lamont-Doherty Earth Observatory of Columbia University, Palisades, NY 10964-8000, USA.

${ }^{3}$ Department of Earth Sciences, Syracuse University, Syracuse, NY 13244-1070, USA.

${ }^{4}$ Department of Geological Sciences, University of Michigan, Ann Arbor, MI 48109-1005, USA.

${ }^{5}$ Department of Geology and Environmental Geosciences, Northern Illinois University, DeKalb, IL 60115-2854, USA.

${ }^{6}$ U.S. Geological Survey, Denver, CO 80225, USA.
Gondwana as well as the present-day global plate motion circuit. Challenges for Antarctic science include the presence of ice sheets, ice shelves, and annual sea ice, hence remote sensing over the continent and surrounding oceans is routinely employed. Extensive offshore seismic reflection studies provide information about the evolution of geologic structures and formation of the Antarctic ice sheets. For example, the "Plates and Gates" project (e.g., Maldonado et al., 2007) is examining links between the opening of the Drake and Tasman Passages, and the transition to an icecovered continent. Onshore, techniques such as airborne geophysics provide insight into the geology and form of the continent under the ice. For example, aeromagnetic data along the western flank of the Transantarctic Mountains reveal a faulted margin with the Wilkes subglacial basin, hence casting doubt on a flexural uplift model for the mountains (Armadillo et al., 2007). Another approach to acquire information from interior Antarctica relies on proxies from sediments and glacial deposits. A $1440 \mathrm{Ma}$, A-type rapakivi granite boulder was discovered in glacial till in the Nimrod Glacier region (Goodge et al., 2007). This granite has a $\mathrm{Nd}$-isotope age and detrital zircons that closely resemble granites from the Laurentian province of North America, demonstrating the presence of Laurentia-like crust in East Antarctica. This supports the postulated fit of East Antarctica and Laurentia over 1 billion years ago, initially suggested by the SWEAT hypothesis (i.e., South West U.S. and East Antarctica connection). But the controversy continues, as new aeromagnetic data do not support the SWEAT reconstruction (Finn and Pisarevsky, 2007).

Correlation of the Cambro-Ordovican Ross and Delamerian orogenies of Antarctica and Australia are well established, but puzzling pieces of the Ross orogen occur in New Zealand and Marie Byrd Land. The Robertson Bay terrane 


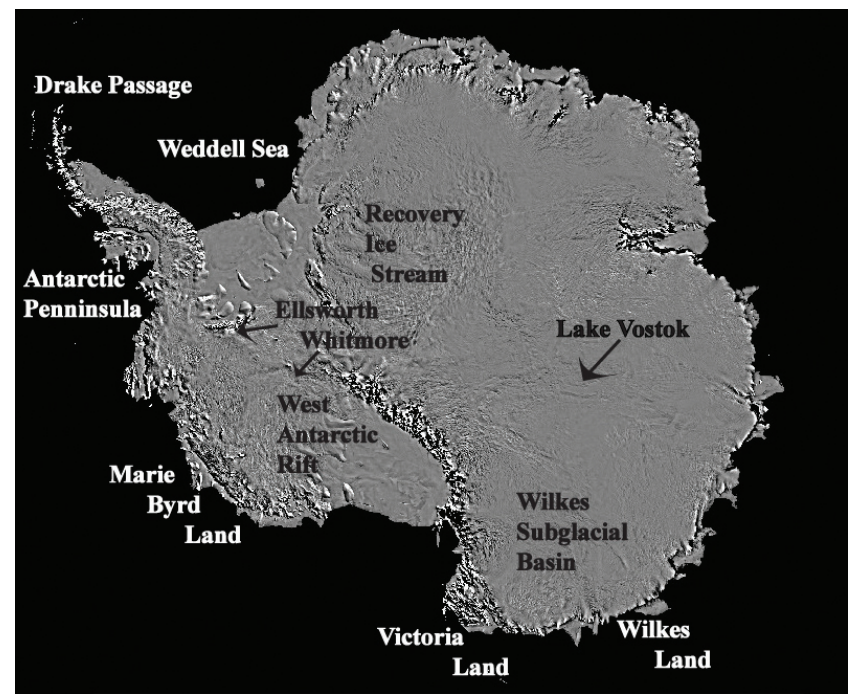

FIGURE 1 Mosaic image map of Antarctica derived from MODIS (Moderate-resolution Imaging Spectroradiometer) satellite data. SOURCE: See http://nsidc.org/data/nsidc-0280.html.

of northern Victoria Land is correlative with the western Lachlan fold belt of eastern Australia, and the Lachlan orogen rocks form in an extensional basin. The Cambrian rocks (Ross orogen correlatives) in New Zealand and Marie Byrd Land simply represent parts of a continental rift margin on the outboard side of the Lachlan fold belt (Bradshaw, 2007).

New models have been proposed for the origin of the West Antarctic rift system and the associated Transantarctic Mountains. Considerable debate at the symposium centered on the plateau hypothesis, in which the West Antarctic rift system and Transantarctic Mountains are thought to have been previously a high-topography plateau with thicker than normal crust. The proposed West Antarctic plateau is inferred to have collapsed in the Cretaceous during extension between East and West Antarctica. The Transantarctic Mountains are, in this hypothesis, the remnant western edge of the plateau modified by rift-flank uplift and glacial erosion. The first numerical model of the concept shows that plateau collapse could generate a remnant edge, depending on initial conditions (Bialas et al., 2007). The geological and thermochronologic evidence for the West Antarctic plateau formation and collapse, along with the tectonic implications, are discussed by Fitzgerald et al. (2007). Evidence for a drainage reversal in the Byrd Glacier region supports the presence of the West Antarctic plateau in the Mesozoic (Huerta, 2007). A synthesis of research from the exposed portion of the rift in Marie Byrd Land demonstrates that elevated crustal temperatures were attained by $140 \mathrm{Ma}$, causing voluminous melting, with lateral migration into wrench structures (Siddoway, 2008, this volume). Presence of melt aided the rapid evolution of the Cretaceous rift.

Other new geodynamic models of Antarctica were advanced at the symposium, emphasizing the significance of Antarctica to studies of global geodynamics (see Figure 1). Sutherland (2008, this volume) presents a model for extension in the West Antarctic rift system, a model that fits well with global plate model circuits and the geology of New Zealand. An elegant "double-saloon-door seafloor spreading" model explains the breakup of Gondwana, magnetic anomalies in the Weddell Sea region, along with the rotation and translation of the Falkland Islands block and the Ellsworth-Whitmore Mountains crustal block (Martin, 2007).

\section{LIFE IN ANTARCTICA: THE TERRESTRIAL VIEW}

A definitive incremental change in our understanding of the evolution of life on Antarctic land emerged at the symposium, from the rich and diverse terrestrial presentations. Evidence of a vibrant world is preserved in nonglacial and glacial sedimentary deposits that rest on top of the tectonic basement structures.

Insights into Gondwana ecosystem dynamics are being gleaned from tracks of animals in Devonian deserts (Bradshaw and Harmsen, 2007); the climate records in Permian, Triassic, and Jurassic floras (Bomfleur et al., 2007; Miller and Isbell, 2007; Ryberg and Taylor, 2007); and the Triassic and Jurassic reptiles and dinosaurs of the Transantarctic Mountains (Collinson and Hammer, 2007; Smith et al., 2007).

For the last 100 million years, from the Late Cretaceous onward, the Antarctic continent has been situated over the South Pole in approximately its present location. In sharp contrast to current frigid polar conditions, abundant subtropical fossil plants are commonly found in Antarctic rocks. The subtropical nature of these fossil plants indicates warm, humid climates at high latitudes during the mid-Cretaceous (Francis et al., 2008, this volume). A variety of dinosaurs lived in these polar forests, as shown by the wealth of bones collected from the Antarctic Peninsula region. The Late Cretaceous dinosaur fauna is a relict of a cosmopolitan dinosaur assemblage that survived until the end of the Cretaceous in Antarctica after becoming extinct elsewhere (Case, 2007). Discoveries of juvenile marine reptile fossils indicate that Antarctica may have been a nursery for young marine reptiles (Martin et al., 2007).

The plant record reveals an interesting conundrum about the terrestrial response to the major climate transition from greenhouse to icehouse during the latest Eocene-earliest Oligocene. Analyses of fossil leaf collections from the Antarctic Peninsula show a temperature decline from warm temperate to cold climates through the Eocene. These cold Eocene climates may have had winter frosts coinciding with a decline in plant diversity (Francis et al., 2008, this volume). A similar cooling trend dominates the marine isotope record. In contrast, the offshore pollen record, recovered from Integrated Ocean Drilling Program (IODP) cores, indicates only short-term responses to individual cooling events and fairly 
stable land temperatures through the Oligocene (Grube and Mohr, 2007).

The newly identified fossil plant record shows that even during the Antarctic icehouse, the continent was not barren and supported a diverse ecosystem. Recent discoveries of fossil plants and insects in the Dry Valleys shows that small bushes of southern beech, Nothofagus, along with mosses and beetles, persisted in Antarctica during the mid-Miocene (Ashworth et al., 2007). A rich fossil assemblage of dwarf beeches, beetles, a fly, snails, fish, mosses, and cushion plants is also preserved in the Sirius Group high in the Beardmore region, sandwiched between glacial tillites (Ashworth et al., 2007; Francis et al., 2008). Although the marine record points to an increasingly ice-covered continent, life continued on land.

The convergence of paleontology and modern biology is producing advances in our understanding of biodiversity in Antarctica. Molecular studies of the scant living Antarctic biotas-mosses, mites, springtails-indicate an origin for these biotas in Antarctica over 40 million years ago (Convey et al., 2007). The Miocene mosses recently discovered in the Dry Valleys are identical to species living today in Antarctica. High-altitude nunataks and ice-free coastal niches must have existed during glacial times to act as refugia for these animals and plants.

Examining the biochemical role of early ice sheets and the development of Earth's atmosphere, Raub and Kirschvinck (2008, this volume) discuss the link between intense global glaciations and atmospheric oxygen generation. Geochemical evidence associated with all three prePhanerozoic glacial events shows that "whiffs to gigantic bursts" of oxygen accompany deglaciation. The increasing oxygen in the atmosphere is attributed to UV photochemistry producing $\mathrm{H}_{2} \mathrm{O}_{2}$ that remains locked in the ice until deglaciation. Upon deglaciation the peroxide decomposes to molecular $\mathrm{O}_{2}$. In their model the ice sheets are a crucial part of an inorganic mechanism that drives the evolution of the oxygen-mediating enzymes that predate oxygenic photosynthesis.

\section{UNDERSTANDING THE CHANGING PLANET: THE PALEOCLIMATE VIEW}

Significant progress has been made regarding Antarctica's Neogene-Pleistocene climate and its role in the global climate system, based on recently collected data. Studies of geologic proxies at various timescales from decadal-centurial to millennial and millions of years are under way to resolve the paleoclimatic events, including the important Paleogene "Greenhouse to Icehouse" transition for the Antarctic region. The many varied studies will continue throughout the International Polar Year and beyond.

Since the 9th ISAES in 2003, scientific rock drilling has made significant advances under the umbrella of the Scientific Committee on Antarctic Research's (SCAR's) ACE
(Antarctic Climate Evolution) program. Several different initiatives are ongoing in the form of ANDRILL (Antarctic Geological Drilling) and SHALDRIL (Shallow Drilling). Drilling will continue with a long anticipated IODP cruise to the Wilkes Land margin that is now scheduled during the International Polar Year.

The first drilling season of ANDRILL in the McMurdo Ice Shelf Project yielded an unprecedented record of at least 60 ice-sheet fluctuations in the past $13 \mathrm{Ma}$, with indications of both warmer-than-present climate and ice sheets in the pre-Pleistocene period (Naish et al., 2008, this volume). ANDRILL and its predecessor Cape Roberts Project have successfully demonstrated that rock drilling from an icebased platform is a viable means to acquire critically needed long, continuous rock cores.

Seismic reflection surveys of offshore regions complement the advances in rock coring, extending the record of paleoclimate events and ice-sheet history beyond the vicinity of the drill sites (Decesari et al., 2007). With new technology the acquisition of seismic data over land-fast sea ice and ice shelves is becoming more efficient and reliable, and multichannel seismic reflection data more readily accessible (Wardell et al., 2007). With new drilling core and seismic surveys, the age and lithology for prominent regional reflectors and units are now better constrained. The new seismic datasets are helping to identify coring and drilling sites and map the extent of past ice-sheet grounding events (Pekar et al., 2007). Land-based geologic studies are providing significant new data that complement the insights emerging from the marine studies. Areas of focused studies are permafrost and Paleogene-Neogene outcrops of paleoclimatic significance. There has been a renewed focus on permafrost and cryosol studies under the auspices of SCAR's Antarctic Permafrost and Soils group. These studies are targeting a broad range of ages from the modern to millions of years, leveraging this sensitive index of climatic change (Kowalewski and Marchant, 2007; Vieira et al., 2007).

\section{FRONTIERS ENCASED IN ICE: A VIEW OF SUBGLACIAL LAKES}

Exactly 50 years ago, during the last International Polar Year, the former Soviet Union established a research base in the deep interior of the Antarctic continent to be close to the geomagnetic South Pole. It was not until several decades later that it was realized from radio echograms that the station was actually located on ice floating on a lake of liquid water. Named Lake Vostok, this water body has about the same surface area as Lake Ontario, but is three times deeper, and is capped by almost $4 \mathrm{~km}$ of ice. Subsequent explorations have produced an inventory of some 145 subglacial lakes, a number that is likely to grow over the next few years.

Rapid changes in our understanding of subglacial lakes emerged at the symposium. Presentations focused on a number of topics, including inventory, tectonic controls for 
formation of the lakes (Bell et al., 2007), expanding demonstration of lake interconnectedness (Carter et al., 2007), recent discovery of the association between subglacial lakes and ice streams (Fricker et al., 2007), lake-water discharge into the oceans and its potential impact on climate, as well as International Polar Year activities gearing up to explore various subglacial aquatic environments.

Geophysical evidence indicates that at least some of the large lakes are structurally controlled, often exploiting the zones of weakness separating distinct terranes. A detrital zircon recovered from the Vostok ice core (Leitchenkov et al., 2007) yielded ages that clustered between $0.8 \mathrm{Ga}$ and $1.2 \mathrm{Ga}$ and between $1.6 \mathrm{Ga}$ and $1.8 \mathrm{Ga}$, and supports the concept that the large lakes form along tectonic boundaries. This is ample evidence for the close juxtaposition of basement rocks with a variety of ages in the interior of the East Antarctic Craton, evidently providing basins in which lakes have formed.

A profound discovery of recent years is the interconnectedness of these lakes with subglacial rivers and wetlands. Liquid water is verifiably on the move in many places beneath the ice sheet, and may have profound influence on ice-sheet stability and overall climate. Motion of water along the axis of ice streams is documented for the Recovery Ice Stream by Fricker et al. (2007).

\section{THE NEXT BREAKTHROUGHS: A VIEW TO THE FUTURE}

Today, understanding the changes in the polar regions is imperative for our global society, global economy, and global environment. As study of planetary change is critical to all Earth science, knowledge of Antarctica and Antarctic Earth science has never been more important. Convened at the beginning of the International Polar Year 2007-2008, the 10th ISAES was a successful opportunity for our global scientific community to share results, data, and ideas and to plan future cooperative programs.

The International Polar Year 2007-2008 is motivated by both our changing planet and the quest to explore unknown frontiers, both being central to Antarctic Earth science (Bell, 2008 , this volume). The work accomplished in the next two years will define future research directions, and collaborations established during the International Polar Year will serve as the basis for decades of future research programs. Antarctica is a global keystone in the Earth system. Antarctic earth science must be both international and global to remain relevant. At the 11th ISAES meeting in four years time, new breakthroughs will be presented based on the International Polar Year results, to enhance the knowledge gained at the 10th ISAES. Fridtjof Nansen noted that humankind is driven to seek knowledge "till every enigma has been solved" (Nansen and Sverdrup, 1897).

\section{REFERENCES}

Armadillo, E., F. Ferraccioli, A. Zunino, and E. Bozzo. 2007. Aeromagnetic anomaly patterns reveal buried faults along the eastern margin of the Wilkes Subglacial Basin (East Antarctica). In Antarctica: A Keystone in a Changing World-Online Proceedings for the Tenth International Symposium on Antarctic Earth Sciences, eds. Cooper, A. K., C. R. Raymond et al., USGS Open-File Report 2007-1047. Short Research Paper 091, doi:10.3133/of2007-1047.srp091.

Ashworth, A. C., A. R. Lewis, D. R. Marchant, R. A. Askin, D. J. Cantrill, J. E. Francis, M. J. Leng, A. E. Newton, J. I. Raine, M. Williams, and A. P. Wolfe. 2007. The Neogene biota of the Transantarctic Mountains. In Antarctica: A Keystone in a Changing World-Online Proceedings for the Tenth International Symposium on Antarctic Earth Sciences, eds. Cooper, A. K., C. R. Raymond et al., USGS Open-File Report 2007 1047, Extended Abstract 071, http://pubs.usgs.gov/of/2007/1047/.

Bell, R. E. 2008, this volume. Antarctic Earth system science in the International Polar Year 2007-2008. In Antarctica: A Keystone in a Changing World, eds. Cooper et al. Washington, D.C.: The National Academies Press.

Bell, R. E., M. Studinger, and C. A. Finn. 2007. Tectonic control of subglacial lakes and ice sheet stability. In Antarctica: A Keystone in a Changing World-Online Proceedings for the Tenth International Symposium on Antarctic Earth Sciences, eds. Cooper, A. K., C. R. Raymond et al., USGS Open-File Report 2007-1047. Extended Abstract 040, http://pubs. usgs.gov/of/2007/1047/.

Bialas, R. W., W. R. Buck, M. Studinger, and P. G. Fitzgerald. 2007. Plateau collapse model for the Transantarctic Mountains/West Antarctic rift system: Insights from numerical experiments. In Program Book for the 10th International Symposium on Antarctic Earth Sciences, eds. A. K. Cooper et al. Short Summary 2.PS-49, p. 69. In Antarctica: A Keystone in a Changing World-Online Proceedings for the Tenth International Symposium on Antarctic Earth Sciences, eds. Cooper, A. K., C. R. Raymond et al., USGS Open-File Report 2007-1047, doi:10.3133/of2007-1047.

Bomfleur, B., J. Schneider, R. Schoner, L. Viereck-Gotte, and H. Kerp. 2007. Exceptionally well-preserved Triassic and Early Jurassic floras from North Victoria Land, Antarctica. In Antarctica: A Keystone in a Changing World-Online Proceedings for the Tenth International Symposium on Antarctic Earth Sciences, eds. Cooper, A. K., C. R. Raymond et al., USGS Open-File Report 2007-1047, Extended Abstract 034, http://pubs. usgs.gov/of/2007/1047/.

Bradshaw, J. D. 2007. The Ross orogen and Lachlan Fold belt in Marie Byrd Land, Northern Victoria Land and New Zealand: Implication for the tectonic setting of the Lachlan Fold belt in Antarctica. In Antarctica: A Keystone in a Changing World-Online Proceedings for the Tenth International Symposium on Antarctic Earth Sciences, eds. Cooper, A. K., C. R. Raymond et al., USGS Open-File Report 2007-1047. Short Research Paper 059, doi:10.3133/of2007-1047.srp059.

Bradshaw, M. A., and F. J. Harmsen. 2007. The paleoenvironmental significance of trace fossils in Devonian sediments (Taylor Group), Darwin Mountains to the Dry Valleys, southern Victoria Land. In Antarctica: A Keystone in a Changing World-Online Proceedings for the Tenth International Symposium on Antarctic Earth Sciences, eds. Cooper, A. K., C. R. Raymond et al., USGS Open-File Report 2007-1047, Extended Abstract 133, http://pubs.usgs.gov/of/2007/1047/.

Carter, S. P., D. D. Blankenship, D. A. Young, and J. W. Holt. 2007. Ice surface anomalies, hydraulic potential and subglacial lake chains in East Antarctica. In Antarctica: A Keystone in a Changing World-Online Proceedings for the Tenth International Symposium on Antarctic Earth Sciences, eds. Cooper, A. K., C. R. Raymond et al., USGS Open-File Report 2007-1047, Extended Abstract 142, http://pubs.usgs. gov/of/2007/1047/. 
Case, J. A. 2007. Opening of the Drake Passage: Does this event correlate to climate change and biotic events from the Eocene La Meseta Formation, Seymour Island, Antarctic Peninsula? In Antarctica: A Keystone in a Changing World-Online Proceedings for the Tenth International Symposium on Antarctic Earth Sciences, eds. Cooper, A. K., C. R. Raymond et al., USGS Open-File Report 2007-1047, Extended Abstract 117, http://pubs.usgs.gov/of/2007/1047/.

Collinson, J. W., and W. R. Hammer. 2007. Migration of Triassic tetrapods to Antarctica. In Antarctica: A Keystone in a Changing World-Online Proceedings for the Tenth International Symposium on Antarctic Earth Sciences, eds. Cooper, A. K., C. R. Raymond et al., USGS Open-File Report 2007-1047, Extended Abstract 047, http://pubs.usgs. gov/of/2007/1047/.

Convey, P., J. A. E. Gibson, D. A. Hodgson, P. J. A. Pugh, and M. I. Stevens. 2007. New terrestrial biological constraints for Antarctic glaciation. In Antarctica: A Keystone in a Changing World-Online Proceedings for the Tenth International Symposium on Antarctic Earth Sciences, eds. Cooper, A.K., C. R. Raymond et al., USGS Open-File Report 20071047, Extended Abstract 053, http://pubs.usgs.gov/of/2007/1047/.

Cooper, A. K., C. R. Raymond, and the ISAES Editorial Team. 2007. Antarctica: A Keystone in a Changing World-Online Proceedings for the Tenth International Symposium on Antarctic Earth Sciences, USGS Open-File Report 2007-1047, doi:10.3133/of2007-1047.

Decesari, R. C., C. C. Sorlien, B. P. Luyendyk, D. S. Wilson, L. Bartek, J. Diebold, and S. E. Hopkins. 2007. Regional seismic stratigraphic correlations of the Ross Sea: Implications for the tectonic history of the West Antarctic Rift System. In Antarctica: A Keystone in a Changing World-Online Proceedings for the Tenth International Symposium on Antarctic Earth Sciences, eds. Cooper, A.K., C. R. Raymond et al., USGS Open-File Report 2007-1047, Short Research Paper 052, doi: 10.3133/of2007-1047.srp052.

Finn, C. A., and S. Pisarevesky. 2007. New airborne magnetic data evaluate SWEAT reconstruction. In Antarctica: A Keystone in a Changing World-Online Proceedings for the Tenth International Symposium on Antarctic Earth Sciences, eds. Cooper, A.K., C. R. Raymond et al., USGS Open-File Report 2007-1047, Extended Abstract 170, http://pubs. usgs.gov/of/2007/1047/.

Fitzgerald, P. G., R. W. Bialas, W. R. Buck, and M. Studinger. 2007. A plateau collapse model for the formation of the West Antarctic rift system/Transantarctic Mountains. In Antarctica: A Keystone in a Changing World-Online Proceedings for the Tenth International Symposium on Antarctic Earth Sciences, eds. Cooper, A. K., C. R. Raymond et al., USGS Open-File Report 2007-1047, Extended Abstract 087, http://pubs. usgs.gov/of/2007/1047/.

Francis, J. E., A. Ashworth, D. J. Cantrill, J. A. Crame, J. Howe, R. Stephens, A.-M. Tosolini, and V. Thorn. 2008, this volume. 100 million years of Antarctic climate evolution: Evidence from fossil plants. In Antarctica: A Keystone in a Changing World, eds. A. K. Cooper et al. Washington, D.C.: The National Academies Press.

Fricker, H. A., R. E. Bell, and T. A. Scambos. 2007. Water budget through a series of interconnected subglacial lakes on Recovery Ice Stream, East Antarctica. In Program Book for the 10th International Symposium on Antarctic Earth Sciences, eds. A. K. Cooper et al. Short Summary 1.P2. B-3, p. 38. In Antarctica: A Keystone in a Changing World-Online Proceedings for the Tenth International Symposium on Antarctic Earth Sciences, eds. Cooper, A. K., C. R. Raymond et al., USGS Open-File Report 2007-1047, doi:10.3133/of2007-1047.

Goodge, J. W., D. M. Brecke, C. M. Fanning, J. D. Vervoort, I. S. Williams, and P. Myrow. 2007. Pieces of Laurentia in East Antarctica. In Antarctica: A Keystone in a Changing World-Online Proceedings for the Tenth International Symposium on Antarctic Earth Sciences, eds. Cooper, A. K., C. R. Raymond et al., USGS Open-File Report $2007-$ 1047, Extended Abstract 055, http://pubs.usgs.gov/of/2007/1047/.
Grube, R., and B. Mohr. 2007. Deterioration and/or cyclicity? The development of vegetation and climate during the Eocene and Oligocene in Antarctica. In Antarctica: A Keystone in a Changing World-Online Proceedings for the Tenth International Symposium on Antarctic Earth Sciences, eds. Cooper, A. K., C. R. Raymond et al., USGS Open-File Report 2007-1047, Extended Abstract 075, http://pubs.usgs. gov/of/2007/1047/.

Huerta, A. D. 2007. Byrd drainage system: Evidence of a Mesozoic West Antarctic Plateau. In Antarctica: A Keystone in a Changing World-Online Proceedings for the Tenth International Symposium on Antarctic Earth Sciences, eds. Cooper, A. K., C. R. Raymond et al., USGS Open-File Report 2007-1047, Extended Abstract 091, http://pubs. usgs.gov/of/2007/1047/.

Kowalewski, D. E., and D. R. Marchant. 2007. Quantifying sublimation of buried glacier ice in Beacon Valley. In Antarctica: A Keystone in a Changing World-Online Proceedings for the Tenth International Symposium on Antarctic Earth Sciences, eds. Cooper, A. K., C. R. Raymond et al., USGS Open-File Report 2007-1047, Extended Abstract 115, http://pubs.usgs.gov/of/2007/1047/.

Leitchenkov, G. L., B. V. Belyatsky, N. V. Rodionov, and S. A. Sergeev. 2007. Insight into the geology of the East Antarctic hinterland: Study of sediment inclusions from ice cores of the Lake Vostok borehole. In Antarctica: A Keystone in a Changing World-Online Proceedings for the Tenth International Symposium on Antarctic Earth Sciences, eds. Cooper, A. K., C. R. Raymond et al., USGS Open-File Report 2007 1047, Short Research Paper 014, doi:10.3133/of2007-1047.srp014.

Maldonado, A., F. Bohoyo, J. Galindo-Zaldivar, F. J. Hernandez-Molina, F. J. Lobo, A. A. Shreyder, and E. Surinach. 2007. Early opening of Drake Passage: Regional seismic stratigraphy and paleoceanographic implications. In Antarctica: A Keystone in a Changing World-Online Proceedings for the Tenth International Symposium on Antarctic Earth Sciences, eds. Cooper, A. K., C. R. Raymond et al., USGS Open-File Report 2007-1047, Extended Abstract 057, http://pubs.usgs. gov/of/2007/1047/.

Martin, A. K. 2007. Double-saloon-door seafloor spreading: A new theory for the breakup of Gondwana. In Antarctica: A Keystone in a Changing World-Online Proceedings for the Tenth International Symposium on Antarctic Earth Sciences, eds. Cooper, A. K., C. R. Raymond et al., USGS Open-File Report 2007-1047, Extended Abstract 112, http://pubs. usgs.gov/of/2007/1047/.

Martin, J. E., J. F. Sawyer, M. Reguero, and J. A. Case. 2007. Occurrence of a young elasmosaurid plesiosaur skeleton from the Late Cretaceous (Maastrichtian) of Antarctica. In Antarctica: A Keystone in a Changing World-Online Proceedings for the Tenth International Symposium on Antarctic Earth Sciences, eds. Cooper, A. K., C. R. Raymond et al., USGS Open-File Report 2007-1047, Short Research Paper 066, doi: 10.3133/of2007-1047.srp066.

Miller, M., and J. Isbell. 2007. Abrupt (how abrupt?) Permian-Triassic changes in southern polar ecosystems. In Program Book for the 10th International Symposium on Antarctic Earth Sciences eds. A. K. Cooper et al. Short Summary 2.P1.B-3, p. 57. In Antarctica: A Keystone in a Changing World-Online Proceedings for the Tenth International Symposium on Antarctic Earth Sciences, eds. Cooper, A. K., C. R. Raymond et al., USGS Open-File Report 2007-1047, doi:10.3133/of2007-1047.

Naish, T. R., R. D. Powell, P. J. Barrett, R. H. Levy, S. Henrys, G. S. Wilson, L. A. Krisse, F. Niessen, M. Pompilio, J. Ross, R. Scherer, F. Talarico, A. Pyne, and the ANDRILL-MIS Science team. 2008, this volume. Late Cenozoic climate history of the Ross Embayment from the AND-1B drill hole: Culmination of three decades of Antarctic margin drilling. In Antarctica: A Keystone in a Changing World, eds. A. K. Cooper et al. Washington, D.C.: The National Academies Press.

Nansen, F., and O. N. Sverdrup. 1897. Farthest North: Being the Record of a Voyage of Exploration of the Ship "Fram" 1893-96, and of a Fifteen Months' Sleigh Journey by Dr. Nansen and Lieut. Johansen. New York: Harper. 
Pekar, S. F., M. A. Speece, D. M. Harwood, F. Florindo, and G. Wilson. 2007. Using new tools to explore undiscovered country. In Antarctica: A Keystone in a Changing World-Online Proceedings for the Tenth International Symposium on Antarctic Earth Sciences, eds. Cooper, A. K., C. R. Raymond et al., USGS Open-File Report 2007-1047, Extended Abstract 169, http://pubs.usgs.gov/of/2007/1047/.

Raub, T. D., and J. L. Kirschvinck. 2008, this volume. A Pan-Precambrian link between deglaciation and environmental oxidation. In Antarctica: A Keystone in a Changing World, eds. A. K. Cooper et al. Washington, D.C.: The National Academies Press.

Ryberg, P. E., and E. L. Taylor. 2007. Silicified wood from the Permian and Triassic of Antarctica: Tree rings from polar paleolatitudes. In Antarctica: A Keystone in a Changing World-Online Proceedings for the Tenth International Symposium on Antarctic Earth Sciences, eds. Cooper, A. K., C. R. Raymond et al., USGS Open-File Report $2007-$ 1047, Short Research Paper 080, doi:10.3133/of2007-1047.srp080.

Siddoway, C. S. 2008, this volume. Tectonics of the West Antarctic rift system: New light on the history and dynamics of distributed intracontinental extension. In Antarctica: A Keystone in a Changing World, eds. A. K. Cooper et al. Washington, D.C.: The National Academies Press.

Smith, N. D., P. J. Makovicky, D. Pol, W. R. Hammer, and P. J. Currie. 2007. The dinosaurs of the Early Jurassic Hanson Formation of the Central Transantarctic Mountains: Phylogenetic review and synthesis. In Antarctica: A Keystone in a Changing World-Online Proceedings for the Tenth International Symposium on Antarctic Earth Sciences, eds. Cooper, A. K., C. R. Raymond et al., USGS Open-File Report $2007-$ 1047, Short Research Paper 003, doi:10.3133/of2007-1047.srp003.
Sutherland, R. 2008, this volume. The significance of Antarctica for studies of global geodynamics. In Antarctica: A Keystone in a Changing World, eds. A. K. Cooper et al. Washington, D.C.: The National Academies Press.

Vieira, G., M. Ramos, S. Gruber, C. Hauck, and J. Blanco. 2007. The permafrost environment of northwest Hurd Peninsula (Livingston Island, Maritime Antarctic): Preliminary results. In Antarctica: A Keystone in a Changing World-Online Proceedings for the Tenth International Symposium on Antarctic Earth Sciences, eds. Cooper, A. K., C. R. Raymond et al., USGS Open-File Report 2007-1047, Extended Abstract 206, http://pubs.usgs.gov/of/2007/1047/.

Wardell, N., J. R. Childs, and A. K. Cooper. 2007. Advances through collaboration: Sharing seismic reflection data via the Antarctic Seismic Data Library System for Cooperative Research (SDLS). Antarctica: A Keystone in a Changing World-Online Proceedings for the Tenth International Symposium on Antarctic Earth Sciences, eds. Cooper, A. K., C. R. Raymond et al., USGS Open-File Report 2007-1047, Short Research Paper 001, doi:10.3133/of2007-1047.srp001. 